\title{
Development of learning module based on blended learning in network design lesson
}

\author{
Panyahuti $^{1}$, Kasman Rukun ${ }^{2}$, Waskito ${ }^{3}$ \\ ${ }^{123}$ Universitas Negeri Padang, Padang Indonesia, (p.matondang@gmail.com)
}

\begin{abstract}
This research is written based on the learning difficulties during the internship activities. This research is to produce learning module for students who implement internship with Blended Learning model. Web-based or Android-based e-learning with the combined method of online manual learning can overcome these obstacles, because it can serve the students in large quantities, the time required is relatively short,it is flexible learning process, and teaching materials can be absorbed quite effectively. The purpose to know the validity of modules, the effectiveness, and effectiveness of the developed learning modules. The method used is a Research and Development ( $R$ \& D) by using the FOUR D development model that are the definition, design, development, and deployment. The research design used for trial module is quasi experiment with time series model. The module made is valid by the material expert with the average of all eligibility is $80.38 \%$, included in the "Excellent" category. The modular practicality analysis is $81.41 \%$, included in the "Practical" category. Module effectiveness analysis, included in the "Good" category. From both data analysis results done, it can be stated that the module is effective in improving learning outcomes.
\end{abstract}

Keywords: blended learning, based learning, industrial work practices, learning module

\section{Introduction}

Implementation of industrial work practices carried out in SMK for at least three months, has eliminated the manual learning in class, this causes the target achievement of learning materials that should be taught by teachers become hampered. So some topics can not be taught to students. With the existence of the problem, it is necessary to add learning activities conducted by subject teachers, when students carry out internship, but the learning activities do not disrupt program. Independent learning activities must be controlled by the teacher.

Additional learning that can be done when students are doing Prakerininternship is online learning. Blended learning becomes one of the options that can be implemented as a solution to the problems of Internship student participants. According to Surjono (2013: 6) blended learning is a learning that combines all forms of learning such as online, live, or face to face (conventional). Before students carry out internship teachers conduct face-to-face lessons in class to provide direction what students should do, how to do it and all the requirements of learning. As long as students carry out 
internship, teachers deliver materials and students can still learn to use existing online media. Online media can be e-learning, email, social media, and etc.

Some researchers have found the effectiveness of using blended learning for students. Utami (2015) has written a research "Development of Blended Learning Model On Basic Network Subject at SMK Negeri 1 Lintau Buo". This research used R \& D method, with IDI development model (Instructional Development Institute) which consists of three stages: define, develop and evaluate. The result of the research was the writer found the blended learning model which was valid, practical and effective.

Izuddin Syari (2012) has written a research about the Effect of Blended Learning Model on Students' Motivation and Student Achievement of SMK. This study aimed to determine differences in student motivation and achievement in subjects KKPI between students using face-to-face learning model and students using blended learning model, increasing motivation and student achievement in subjects KKPI due to the application of blended learning model, and the interaction of the influence of the application of learning model and motivation to learning achievement of KKPI of SMKN 1 Paringin students. The quasi-experimental study used two groups, the experimental group using blended learning model and control group using face-to-face learning model. The result of the research showed that there was a significant difference between students' motivation and achievement using blended learning model and students using face-to-face learning model, there was a significant increase in motivation and student achievement due to the application of blended learning model, and there was no interaction of influence application of learning model and motivation to student achievement.

The purpose of this study is to produce a learning module Designing Network with blended learning based learning model, and to determine the validity, practicality and effectiveness of the modules developed.

\section{Method}

This research is development research with Four-D development model. This model consists of 4 development stages: Define Design, Develop, and Disseminate. The research produces a Designing Network learning module that can be used by SMK Negeri 1 Lahat students, at the time of the implementation of Industrial Work Practice. Modules and tasks are distributed through e-Learning accessible on the lms.smkn1lahat.sch.id page. The research subjects is from grade XI Computer and Network Engineering students with the number of students 36 people.

Data collection techniques were conducted using questionnaires and test results of learning. The research instrument used is module validation sheet by material expert and media expert, student questionnaire and learning result assessment.

The module that has been made is tested to the students of class XI TKJ SMK Negeri 1 Lahat. Lesson material to be attempted a) Internet and its utilization; b) Planning for network updating c) Planning of Address Structure.

The research design uses Quasi Experimental design with Time Series Design. In this type of study the group under study can not be selected randomly, there is no control group. But only one group measured and observed the symptoms that emerged after being treated / posttest (Sugiyono, 2015: 507). The research design is as follows:

Table 1. Times Series Designs

\begin{tabular}{ccc}
\hline Pretest & Treatment & Posttest \\
\hline O1 O2 O3 04 & $\mathrm{X}$ & O5 O6 O7 O8 \\
\hline
\end{tabular}

Source: Sugiyono. 2015. Metode Penelitian \& Pengembangan Research and Development 
$\mathrm{O} 1, \mathrm{O} 2, \mathrm{O} 3 \mathrm{O} 4=$ Pretest 1 to pretest 3

$\mathrm{X} \quad=$ Treatment, It is learning by using module.

O5, O6, O7 O8 =The result of observation after done, the result of student learning and student response to learning

The validation analysis of the learning module is done, by searching the average of each category and the average of each aspect in the validation sheet, until finally the average total validation rating of the module is obtained. Expert validation results are compared with the percentage category benchmark table.

Table 2. Percentage Category

$\begin{array}{cc}\text { Percentage } & \text { Category } \\ 80,00-100.00 & \text { Excellent } \\ 60,00-79,99 & \text { Good } \\ 40,00-59,99 & \text { Fair } \\ 00,00-39,99 & \text { Less }\end{array}$

Source: Jakni. 2016. MetodlogiPenelitianEksperimenBidang Pendidikan

Practical Analysis is done by measuring students' responses to the use of modules in learning, the ideal assessment as follows:

$$
\begin{array}{ll}
\text { Prs } & \operatorname{Prs}=\frac{A}{B} X 100 \% \\
\text { A } & \text { Percentage of student responses } \\
\text { B } & \text { Total Number of score answers students } \\
& \text { Table 3. Criteria Practical Category }
\end{array}
$$

\begin{tabular}{cl}
\hline Level of Achievement $\%$ & Category \\
$90-100$ & Very Practical \\
$80-89$ & Practical \\
$65-79$ & Practical Enough \\
$55-64$ & Less Practical \\
$0-54$ & Not Practical \\
\hline
\end{tabular}

Source :Nina Andriani et al (2017) Pengembangan Modul Ajar Kimia Unsur Berbasis Inkuiri Terbimbing Untuk Mahasiswa Pendidikan Kimia

The effectiveness of the module is carried out in two ways: a) analyzing the students' learning outcomes and $b)$ The $t$ test, done by summing the post test $(\mathrm{O} 4+\mathrm{O} 5+\mathrm{O} 6)$ and the pretest $(\mathrm{O} 1+\mathrm{O} 2+$ O3), then testing the difference between the two.

\section{Results and Discussion}

This study produced a learning module with the title "Internet and Network Development Planning" which had been tested, as well as its validity, practicality and effectiveness. To test the validity, the writer asked for help from three experts, they were two material experts and one media experts. Validation instruments were taken from BSNP by adopting the instrument of Textbooks National Standards in 2013.

Modules created were distributed via e-Learning on http://www.lms.smkn1lahat.sch.id page, with PDF and EPUB formats. To facilitate communication between teachers and students and to control the implementation of learning made a group on WhatsAPP application based on Android or IOS. 
The module made was declared valid by the material expert with the overall average scoring score of all expert judgments. The content feasibility was $82,50 \%$, the presentation feasibility was $81,73 \%$, the linguistic feasibility was $82,29 \%$ and the grading feasibility was $75 \%$, the average of all feasibility was $80,38 \%$ included in "Excellent" category.

The result of module practicality analysis was obtained

$$
\begin{aligned}
\text { Prs } & =\frac{2930,83}{4320} \times 100 \% \\
\text { Prs } & =81,41 \%
\end{aligned}
$$

The total percentage of students' answers wass $81.41 \%$ included in the "Practical" category, the module could be concluded practical to be used by students. The analysis of module effectiveness was done in two ways, learning mastery analysis and test difference between pretest and posttest using $t$ test. The results obtained awere the average mastery of students in the learning process using the module for 3 times the posttest implemented, The result was obtained $61 \%$ of classical completeness and it wasincluded in the "Good" category.

For $\mathrm{t}$ test, there was correlation between pretest variable with posttest equal to 0,466 with significant level equal to 0,04 . Because of the significant level was $0.04<0.05$, it could be stated that there is a relationship between the learning outcomes before the module was given and after the module was given. From figure 4.6 paired samples table test obtained $t=14,608$ at $\mathrm{df} 35$. Because $t$ arithmetic $>t$ table was: $14,608>2,43772$ or significant level sig $<0,01$ is $0,000<0,01$, hence there was significant difference before given modules with after being given a learning module. From both data analysis results conducted, it can be stated that the module "Internet and Network Development Planning" is effective in improving learning outcomes.

\section{Conclusions}

This study produces a learning module with the title "Internet and Network Development Planning" which has been tested, as well as its validity, practicality and effectiveness To test the validity, the writer asked for help from three experts, they are two material experts and one media experts. Validation instrument was taken from BSNP by adopting instrument from Textbooks National Standards in 2013.

The module made is declared valid by the material expert with the overall average scoring score of all expert judgments. The content feasibility is $82,50 \%$, the presentation feasibility is $81,73 \%$, the linguistic feasibility is $82,29 \%$ and the grading feasibility is $75 \%$, the average of all feasibility is 80,38\% included in "Excellent" category.

Module practical analysis is done by giving questionnaires to students. The total percentage of students' answers is $81.41 \%$ included in the "Practical" category, the module can be concluded practical for students to be used.

The analysis of module effectiveness is done in two ways, learning mastery analysis and test difference between pretest and posttest using $\mathrm{t}$ test. Based on the students' learning mastery that has been done 3 times in the posttest, the result of the classify feasibility is $61 \%$, included in "Good" category.

Based on these conclusions, learning using blended learning module for students who are practicing internship is one of the solutions to keep carrying out learning during internship activities.

\section{Acknowledgments}


Specials thanks to:

Mr. Fahmi Rizal, M.Pd. MT, Dean of Faculty of Engineering, State University of Padang, Dr. Ambiyar, M.Pd, Dr. Refdinal MT as a contributor who has contributed a lot to the refinement of this thesis.Principal of SMK Negeri 1 Lahat, who has given research permission. Head of Computer Engineering and Informatics Engineering Program SMK Negeri 1 Lahat, who has provided assistance and support in this research. Father, Mother, Father Mother-in-Law and Beloved Wife EvyYosita Silva, M.Pd. Princess and son of Viona Adelia, RizkyAnggianMatondang who has participated to provide assistance both morally materially and prayer to the author in completing this thesis.

\section{References}

Arsyad. (2013). Media Pembelajaran. Jakarta: Rajawali Pers

Bambang Warsita. (2008). Teknologi Pembelajaran Landasan dan Aplikasinya. Jakarta: PT RinekaCipta. Daryanto. (1993). Media Visual untuk Pengajaran Teknik. Bandung: Tarsito

Darmawan Deni. (2014). Pengembangan E-Learning Teori dan Desain. Bandung: Remaja Rosdakarya

Bath, D\&John, B.( 2010).Getting Started with Blended Learning. Brisbane: Griffith University

Wahyuningsih, D. (2017). E-Learning Teori dan Aplikasi. Bandung: Informatika

Ditpsmk, SMK. (2015). Praktik Kerja Lapangan Sekolah Menengah Kejuruan Hand Out Pendampingan Kurikulum 2013 Tahun 2015. Jakarta: Direktorat Pembina SMK

Herman, D.S.(2013). Membangun Course eLearning Berbasis Moodle. Yogyakarta:UNY, 2013

Jogiyanto, J. (2005), Analisis dan Desain Sistem Pendekatan Terstuktur teori dan Praktik Aplikasi Bisnis. Yogyakarta: Andi

Jakni,J. (2016). Metodlogi Penelitian Eksperimen Bidang Pendidikan. Bandung: Alfa Beta.

Wena, M.(1996). Pendidikan System Ganda. Bandung:Tarsito

Sudjana, N.(2004). Teknologi Pengajaran. Bandung: Sinar Baru Algensindo

Andriani, N.\&Aritonga, S.F. (2017). Prosiding Seminar Nasional Kimia Uny 2017 Pengembangan Modul Ajar Kimia Unsur Berbasis Inkuiri Terbimbing Untuk Mahasiswa Pendidikan Kimia. Yogyakarta: UNY

Purbo, W.O.(2002). Teknologii e-Learning Berbasis PHP dan MySQL. Jakarta: PT Elek Media Komputindo.

Rusman, R(2016).Model-model pembelajaran Mengembangkan Profesionalisme Guru, Edisi Kedua. Jakarta: Rajawali Pers.

Seels, B.B. \& Richey, R.C.(2000). Instructional technology, The definition and domains of the field, Terjemahan Dewi S Prawiradilaga, R. Rahardjo, Yusufhadi Miarso. Jakarta: Penerbit IPTPI \& LPTK.

Sofwan, A. (2010). Kontruksi Pengembangan Pembelajaran. Jakarta: Prestasi Pustaka

Sugiyono, S(2015). Metode Penelitian \& Pengembangan Research and Development. Bandung: Alfa Beta. Sugiyono, S. (2006). Metode Penelitian Administrasi. Dilengkapi Metode RED. Bandung: Alfa Beta.

Sutrisno, S. (2011). Pembelajaran Inovatif Berbasis Teknologi Informasi \& Komunikasi. Jakarta: GangPersada.

Suparman, M.A..(2004). Desain Instruksional. Jakarta: Universitas Terbuka Suparman, M.A. (2004). Pendidikan Jarak Jauh Teori dan Praktek. Jakarta: Universitas Terbuka. Nasution, S.(2010). Berbagai Pendekatan dalam Proses Belajar Mengajar. Bandung: Bumi Aksara.

Thiagarajan, S., Semmel, D.S \&Semmel, M. I. (1974). Instructional Development for Training Teachers of Expectional Children. Minneapolis, Minnesota: Leadership Training Institute/Special Education. University of Minnesota: University of Minnesota 